\title{
Blood lipid levels, statin therapy and the risk of intracerebral hemorrhage
}

Yingxu Ma ${ }^{1,2}$, Zhaokai $\mathrm{Li}^{1,2}$, Liang Chen ${ }^{1,2}$ and Xiangping $\mathrm{Li}^{\mathrm{i}^{*}}$

\begin{abstract}
Dyslipidemia has been proven to play an important role in the occurrence and development of the ischemic stroke and lipid-lowering therapy could significantly decrease the risk of the ischemic stroke. However, the association between lipid levels, lipid-lowering therapy and the risk of intracerebral hemorrhage $(\mathrm{ICH})$ is not clear. Studies have shown that low serum levels of total cholesterol might be associated with increasing risk of $\mathrm{ICH}$, whereas the SPARCL study, a large prospective, randomized, placebo-controlled trial, demonstrated an increased risk of hemorrhagic stroke during high-dose statin therapy among the patients with previous stroke. The relationship between lipid-lowering therapy and ICH has become a hot topic in the recent years. We searched PubMed for articles published in English to review the existing evidence on the association of lipid levels, statin therapy and risk of $\mathrm{ICH}$ as well as the underlying mechanisms in order to provide practical recommendations for clinical decision-making and a foundation for further researches.
\end{abstract}

Keywords: Lipids, Statin, Lipid-lowering therapy, Intracerebral hemorrhage

\section{Background}

Stroke is one of the leading causes of death and adult disability in the world. Intracerebral hemorrhage (ICH), an important subtype of the stroke, is characterized by high mortality and morbidity, which contains symptomatic intracerebral hemorrhage $(\mathrm{sICH})$ [1] and cerebral microbleed (CMB) [2]. In ICH patients, perihematomal inflammation where the region becomes infiltrated with neutrophils and activated microglia after the activation of Toll-like receptor 4 [3] and the release of inflammatory mediators such as tumor necrosis factor- $\alpha$ (TNF- $\alpha$ ) and interleukin-1 $\beta$ (IL-1 $\beta$ ) [4] contributes to neuronal injury and functional disability. Meanwhile, ICH results in the change of the cerebral blood flow and the increasing permeability of blood-brain barrier (BBB) [5]. These pathological changes could aggravate nerve damage and dysfunction. The data from World Health Organization (WHO) showed that $\mathrm{ICH}$ accounts for approximately $25-50 \%$ of stroke and the reduction of morbidity and mortality among $\mathrm{ICH}$ patients must remain a public health priority.

\footnotetext{
*Correspondence: lixp@medmail.com.cn

'Department of Cardiology, The Second Xiangya Hospital, Central South University, \#139 Middle Renmin Road, Changsha, Hunan 410011, PR China Full list of author information is available at the end of the article
}

Hyperlipidemia has been proven to be a risk factor of ischemic stroke [6]. Statins which mainly reduce the serum levels of total cholesterol (TC) and low density lipoprotein cholesterol (LDL-C) are widely used or prescribed for the primary and secondary prevention of ischemic strokes and have achieved favourable clinical outcomes. Several clinical studies [1, 7-9] have shown that statin could not increase the risk of $\mathrm{ICH}$ and has been beneficial to $\mathrm{ICH}$ patients as well as promoting their recovery. But a post hoc analysis of the SPARCL trial that was conducted among the patients with stroke demonstrated that atorvastatin was associated with an increased risk of ICH [10]. Furthermore, some epidemiological and case-control studies found that patients with lower serum lipid had an increasing risk of ICH [11-13]. Therefore, it is necessary to further clarify the association of serum lipid levels, statin therapy and the risk of $\mathrm{ICH}$. The systematic review focuses on the research progress in this field derived from epidemiological and clinical evidence. We searched PubMed for basic and clinical studies which were published in English (last search update performed on 31 August 2015). The search strategy was based on the combination of the following terms: lipids, total cholesterol (TC), triglyceride (TG), low density lipoprotein cholesterol (LDL-C), and high density lipoprotein cholesterol (HDL-C), lipid- 
lowering therapy, statins, HMG-CoA reductase inhibitors, stroke and intracerebral hemorrhage.

\section{Blood lipid levels and ICH}

Lipids are essential components of cell membrane, which play an important role in maintaining the stabilization of endothelial cells and the integrity of cerebral small vessels [14]. Epidemiological and case-control studies found a correlation between ICH and the change of blood lipid levels which included TC, TG, LDL-C, and HDL-C.

\section{TG and ICH}

A pooled cohort study of the Atherosclerosis Risk in Communities Study (ARIC) and the Cardiovascular Health Study (CHS) involving 21,680 patients showed that lower TG was a risk factor for ICH and was inversely related to the incidence of $\mathrm{ICH}$ [15]. In a population-based prospective cohort study among 8393 men and women [11], Bonaventure et al. made a quantitative analysis of TG level and the risk of $\mathrm{ICH}$, demonstrating that a low level of triglycerides (serum TG $\leq 0.94 \mathrm{mmol} / \mathrm{L}$ ) was associated with a more than twofold increased risk of ICH [adjusted hazard ratio (HR) 2.35, $95 \%$ confidence interval (CI) 1.18-4.70]. In addition, the Rotterdam Study showed that serum TG levels were associated with the presence of CMB [16], which is a risk marker of sICH [2]. The above results suggest that the low TG might be related to the increasing risk of $\mathrm{ICH}$. On the contrary, in the Malmö Preventive Project [17] involved 33,346 participants (mean age 47 years old), $147 \mathrm{ICH}$ subjects who were followed up (approx. 14 years) had significantly higher TG levels (1.7 vs. $1.4 \mathrm{mmol} / \mathrm{L}$ ) compared with 1029 stroke-free controls, matched for age, sex and screening-year. The multivariate analyses showed there was a positive correlation between TG and the risk of ICH among the lobar ICH (OR 1.7, 95 \% CI 0.9-3.2) and nonlobar ICH (OR 1.4, 95 \% CI 0.90-2.3) patients. Furthermore, a crosssectional study [18] demonstrated that 500 patients with acute ICH had significantly higher TG levels $(P<$ $0.0001)$. The linear regression and correlation analysis suggested that with increased TG, the intracerebral hemorrhagic volumes were gradually increasing.

\section{$\mathrm{TC}$ and $\mathrm{ICH}$}

In a case-control study in 22 countries (the INTERSTROKE study) [13], with blood analyses completed among 2190 cases and 2127 controls who matched for age and sex, researchers found that increased concentration of TC was associated with reduced risk of ICH (OR 0.62, 99 \% CI 0.42-0.92). A meta-analysis [19] that included 23 prospective studies, totaling $1,430,141$ participants with 7960 hemorrhagic strokes $(0.56 \%)$ demonstrated that the summary relative risk of hemorrhagic stroke was 0.69 (95\% CI 0.59-0.81) in high versus low TC analysis. Meanwhile, the summary relative risk of hemorrhagic stroke for $1 \mathrm{mmol} / \mathrm{L}$ increment of TC was 0.85 (95\% CI 0.80-0.91), supporting that TC was inversely related to $\mathrm{ICH}$. And $\mathrm{Su}$ zuki et al. [20] found that serum $\mathrm{TC}<160 \mathrm{mg} / \mathrm{dl}$ correlated with the significantly increased risk of $\mathrm{ICH}$. Furthermore, the Framingham Heart Study [2] comprised 1965 Framingham residents (mean age $66.5 \pm 11.0$ years old; $54 \%$ women) who attended a baseline brain MRI between 1998 and 2008 and underwent it again between 2000 and 2009 . The result revealed that $8.8 \%$ of participants had a CMB between 2000 and 2009. Logistic regression analysis [2] showed that $\mathrm{TC}<10$ th percentile remained associated with the increasing risk of $\mathrm{CMB}$ (OR 1.9; 95 \% CI 1.20-3.03). However, a prospective study [12] including 58,235 Finnish participants (age range 25-74 years old) without a history of coronary heart disease and stroke demonstrated that, after further adjustment for other confounding factors, the inverse association between $\mathrm{TC}$ and ICH is only significant in women but not in men.

\section{LDL-C and ICH}

The meta-analysis conducted by Wang et al. [19] showed that the summary relative risk of hemorrhagic stroke for $1 \mathrm{mmol} / \mathrm{L}$ increment of LDL-C was 0.90 (95\% CI 0.77-1.05), suggesting that high level of LDL-C may reduce the risk of hemorrhagic stroke. Moreover, Mustanoja et al. [21] found that after adjusting for known ICH prognostic factors lower LDL-C levels was independently associated with in-hospital mortality of ICH patients (OR 0.54, 95 \% CI 0.31-0.93).

\section{HDL-C and ICH}

A case-control study [13] showed that the level of HDL$\mathrm{C}$ positively correlated with the risk of ICH (OR 1.91, $99 \%$ CI 1.29-2.83). In addition, higher ratio of nonHDL-C to HDL-C was associated with reduced risk of ICH (OR 0.43, 99 \% CI 0.30-0.62) [13]. A meta-analysis [19] of 19 prospective cohort studies also indicated that the summary relative risk of hemorrhagic stroke for $1 \mathrm{mmol} / \mathrm{L}$ increment of HDL-C was 1.17 (95 \% CI 1.021.35) in a dose-response analysis, which suggested that the increased level of HDL-C may be related to a higher risk of $\mathrm{ICH}$.

Table 1 outlines the details of major studies investigating the relationship between lipid levels and ICH. Most research show that lower TC and LDL-C and higher HDL-C are associated with the increasing risk of $\mathrm{ICH}$. Although the precise mechanisms are still unclear, it was considered that low blood level of TC might contribute to an abnormal fragility of erythrocytes [22] and endothelial cells [23], necrosis of smooth muscle cell in arterial media [19], and angionecrosis [23]. But the 
Table 1 Summary of studies investigating the relationship between lipid levels and ICH

\begin{tabular}{|c|c|c|c|c|c|c|c|c|}
\hline Study & Study design & Sample size & Study population & Mean Age (y); Male (\%) & Follow-Up in Years & Baseline lipid levels(mmol/L) & $\mathrm{ICH}(n)$ & Key study findings \\
\hline $\begin{array}{l}\text { [15] } \\
\text { Sturgeon } \\
\text { et al. } 2007\end{array}$ & $\begin{array}{l}\text { pooled } \\
\text { prospective } \\
\text { cohort study } \\
\text { (including } 2 \\
\text { studies: ARIC } \\
\text { and CHS) }\end{array}$ & 21,680 & $\begin{array}{l}\text { without a history } \\
\text { of stroke, } \\
\text { American }\end{array}$ & $\begin{array}{l}54.2(\mathrm{ARIC}), 72.8(\mathrm{CHS}) ; \\
44.8 \%(\mathrm{ARIC}), 42.4 \% \\
(\mathrm{CHS})\end{array}$ & $3(\mathrm{ARIC}) ; 5(\mathrm{CHS})$ & $\begin{array}{l}\text { TG: } 1.49 \text { (ARIC), } 1.58 \\
\text { (CHS); TC: } 5.56 \text { (ARIC), } \\
5.46 \text { (CHS); LDL-C: } 3.56 \\
\text { (ARIC), } 3.36 \text { (CHS); } \\
\text { HDL-C: } 1.33 \text { (ARIC), } \\
1.40 \text { (CHS) }\end{array}$ & 135 & $\begin{array}{l}\text { TG RR 0.56 (95 \%Cl } 0 \\
.37-0.84) ; \text { LDL-C (top 1/4 } \\
\text { vs. lower 3/4): RR } 0.52 \text { (95 } \\
\% \text { Cl 0.31-0.88) }\end{array}$ \\
\hline $\begin{array}{l}{[11]} \\
\text { Bonaventure } \\
\text { et al. } 2009\end{array}$ & $\begin{array}{l}\text { population- } \\
\text { based } \\
\text { prospective } \\
\text { cohort study }\end{array}$ & 8393 & $\begin{array}{l}\text { without a history } \\
\text { of stroke, French }\end{array}$ & $\geq 65 ; 36.8 \%$ & 5 & $\begin{array}{l}\text { TC: } 5.56(\mathrm{TG} \leq 0.94), \\
5.81(\mathrm{TG} 0.95-1.3), \\
6.08(\mathrm{TG} \geq 1.34) ; \\
\text { LDL-C: } 1.82(\mathrm{TG} \leq 0.94), \\
1.62(\mathrm{TG} 0.95-1.33) \\
1.39(\mathrm{TG} \geq 1.34) ; \mathrm{HDL}-\mathrm{C}: \\
1.82(\mathrm{TG} \leq 0.94), 1.62 \\
(\mathrm{TG} 0.95-1.33), 1.39 \\
(\mathrm{TG} \geq 1.34)\end{array}$ & 36 & $\begin{array}{l}\text { TG } \leq 0.94 \mathrm{mmol} / \mathrm{L}: \text { adjusted } \\
\text { HR } 2.35 \text { (95\%Cl 1.18-4.70) }\end{array}$ \\
\hline $\begin{array}{l}\text { [16] } \\
\text { Wieberdink } \\
\text { et al. } 2011\end{array}$ & $\begin{array}{l}\text { prospective } \\
\text { cohort study }\end{array}$ & 9068 & $\begin{array}{l}\text { without a history } \\
\text { of stroke, Dutch }\end{array}$ & $\geq 55 ; 57.1 \%$ & 9.7 & $\begin{array}{l}\text { TG, median (IQR): } 1.3 \\
\text { (1.0-1.8); TC, median } \\
\text { (IQR): } 5.8(5.2-6.5) ; \\
\text { LDL-C, median (IQR): } \\
\text { 3.7 (3.2-4.3); HDL-C, } \\
\text { median (IQR): } 1.3 \\
\text { (1.1-1.6) }\end{array}$ & $\begin{array}{l}85 ; 162 \\
\text { CMB in } 789 \\
\text { healthy } \\
\text { participants }\end{array}$ & $\begin{array}{l}\text { TG: HR } 0.20 \text { (95 \%Cl 0.06-0.69); } \\
\text { TG (CMB): HR } 0.37 \text { (95 \%Cl 0.14-0.96) }\end{array}$ \\
\hline $\begin{array}{l}\text { [17] Zia et al. } \\
2006\end{array}$ & $\begin{array}{l}\text { population- } \\
\text { based nested } \\
\text { case-control } \\
\text { study }\end{array}$ & $\begin{array}{l}33,346 \\
(1029 \text { stroke-free } \\
\text { controls, matched } \\
\text { for age, sex and } \\
\text { screening-year) }\end{array}$ & $\begin{array}{l}\text { without a history } \\
\text { of myocardial } \\
\text { infarction or } \\
\text { stroke, Swedish }\end{array}$ & $47 ; 67.3 \%$ & 14 & / & 147 & $\begin{array}{l}\text { TG (among the lobar ICH): } \\
\text { OR } 1.7(95 \% \mathrm{Cl} 0.9-3.2) ; \mathrm{TG} \\
\text { (among the nonlobar ICH):OR } \\
1.4(95 \% \mathrm{Cl} 0.9-2.3 \text { ) }\end{array}$ \\
\hline $\begin{array}{l}\text { [18] Zhou } \\
\text { et al. } 2003\end{array}$ & $\begin{array}{l}\text { cross-sectional } \\
\text { study }\end{array}$ & 700 & $\begin{array}{l}\text { without a history } \\
\text { of stroke, Chinese }\end{array}$ & $\geq 57$ & / & / & 500 & $\begin{array}{l}\text { In ICH patients, TG and LDL-C } \\
\text { were significantly increased } \\
(P<0.0001) \text {, HDL-C was } \\
\text { significantly decreased }(P<0.0001)\end{array}$ \\
\hline $\begin{array}{l}{[13]} \\
\text { O'Donnell } \\
\text { et al. } 2010\end{array}$ & $\begin{array}{l}\text { case-control } \\
\text { study }\end{array}$ & 4317 & $\begin{array}{l}\text { be admitted to } \\
\text { hospital with first } \\
\text { acute stroke } \\
\text { whose causes } \\
\text { were vascular, } 22 \\
\text { countries }\end{array}$ & $66.1 ; 63.0 \%$ & 3 & / & 663 & $\begin{array}{l}\text { TC OR } 0.62 \text { (99 \%Cl 0.42-0.92); } \\
\text { HDL-C OR } 1.91 \text { (99 \%Cl 1.29-2.83); } \\
\text { non-HDL-C: } 0.50 \text { (99 \%Cl 0.34-0.72) }\end{array}$ \\
\hline $\begin{array}{l}\text { [19] Wang } \\
\text { et al. } 2013\end{array}$ & $\begin{array}{l}\text { meta-analysis } \\
\text { (19 prospective } \\
\text { cohort studies, } \\
4 \text { nested case- } \\
\text { control studies) }\end{array}$ & $1,430,141$ & / & / & / & / & 7960 & 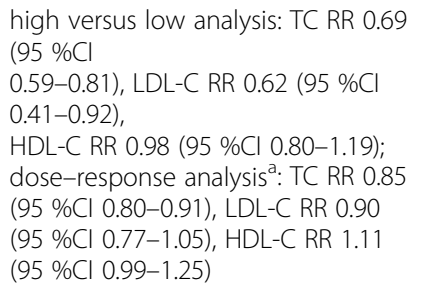 \\
\hline
\end{tabular}


Table 1 Summary of studies investigating the relationship between lipid levels and ICH (Continued)

\begin{tabular}{|c|c|c|c|c|c|c|c|c|}
\hline $\begin{array}{l}\text { [20] Suzuki } \\
\text { et al. } 2010\end{array}$ & $\begin{array}{l}\text { prospective } \\
\text { cohort study }\end{array}$ & & $\begin{array}{l}\text { without a history } \\
\text { of stroke, Japanese }\end{array}$ & & & & & $\begin{array}{l}\text { low TC }(<160 \mathrm{mg} / \mathrm{dl}) \text { was } \\
\text { critical risks of ICH }\end{array}$ \\
\hline $\begin{array}{l}\text { [2] Romero } \\
\text { et al. } 2014\end{array}$ & $\begin{array}{l}\text { prospective } \\
\text { cohort study }\end{array}$ & 1965 & $\begin{array}{l}\text { without a history } \\
\text { of stroke, } \\
\text { American }\end{array}$ & $66.5 ; 66.0 \%$ & 12 & $\begin{array}{l}\text { TC, mean (SD): } 4.95 \text { (0.96); } \\
\text { LDL-C, mean (SD): } 2.84 \\
(0.83)\end{array}$ & 173 & $\begin{array}{l}\text { TC }<10 \text { th percentile: } 1.91 \\
(95 \% \mathrm{Cl} 1.20-3.03) \text {; } \\
\text { LDL-C <10th percentile: } 1.28 \\
(95 \% \mathrm{Cl} 0.75-2.19)\end{array}$ \\
\hline $\begin{array}{l}\text { [12] Zhang } \\
\text { et al. } 2012\end{array}$ & $\begin{array}{l}\text { prospective } \\
\text { cohort study }\end{array}$ & 58,235 & $\begin{array}{l}\text { without a history } \\
\text { of coronary heart } \\
\text { disease or stroke, } \\
\text { Finnish }\end{array}$ & $25-74 ; 47.6 \%$ & 20.1 & I & 497 & $\begin{array}{l}\text { TC in women: }<5 \mathrm{mmol} / \mathrm{L} \\
\text { HR } 1.00,5-5.9 \mathrm{mmol} / \mathrm{L} \mathrm{HR} 0.58 \\
(95 \% \mathrm{Cl} \\
0.38-0.90), 6-6.9 \mathrm{mmol} / \mathrm{L} \\
\mathrm{HR} 0.40-0.94(95 \% \mathrm{Cl} 0.40-0.94) \text {, } \\
\geq 7 \mathrm{mmol} / \mathrm{L} \mathrm{HR} 0.50 \text { ( } 95 \% \mathrm{Cl} \\
0.32-0.78) ; \text { the relationship of } \\
\text { TC and ICH in men was not } \\
\text { significant }\end{array}$ \\
\hline $\begin{array}{l}{[21]} \\
\text { Mustanoja } \\
\text { et al. } 2013\end{array}$ & $\begin{array}{l}\text { observational } \\
\text { registry }\end{array}$ & $\begin{array}{l}964 \text { ( } 187 \text { patients } \\
\text { used statin } \\
\text { before ICH) }\end{array}$ & $\begin{array}{l}\text { Be admitted to } \\
\text { hospital with ICH, } \\
\text { Finnish }\end{array}$ & $66 ; 57.1 \%$ & / & $\begin{array}{l}\text { TG, median (IQR): } 1.0(0.7- \\
1.3) ; \mathrm{TC} \text {, median (IQR): } 4.4 \\
(3.8-5.1) \text {; } \\
\text { LDL-C, median (IQR): } 2.4 \\
\text { (1.8-3.0); HDL-C, median } \\
\text { (IQR):1.4 (1.1.-1.8) }\end{array}$ & 964 & $\begin{array}{l}\text { After adjusting for known } \\
\text { ICH prognostic factors, lower } \\
\text { LDL-C was independently } \\
\text { associated with } \\
\text { in-hospital mortality (OR 0.54, } \\
95 \% \mathrm{Cl} 0.31-0.93 \text { ) }\end{array}$ \\
\hline
\end{tabular}

a for $1 \mathrm{mmol} / \mathrm{L}$ increment 
relationship between TG and $\mathrm{ICH}$ is controversial. The inconsistent results might be due to the different participants involved in the researches or other factors. The subjects who participated in the Malmö Preventive Project [17] were younger and the follow-up period was shorter than those who participated in the projects which had opposite results. In Zhou's cross-sectional study [18] TG level was tested after the acute ICH occurred, which was different from the prospective studies in which TG level was tested before the ICH occurred. Therefore, a higher TG level may be the result of stress [24] instead of a risk factor for ICH. These data suggest that the association between TG and ICH may be inconsistent in different individuals.

\section{Statin therapy and ICH}

Statins, also known as 3-hydroxy-3-methylglutaryl coenzyme A (HMG-CoA) reductase inhibitors, have been widely used clinically. A large number of studies has shown that statin therapy is an effective method for the treatment and prevention of atherosclerotic cardiovascular diseases. However, there is a concern whether lowering lipid levels by statin therapy may increase the risk of ICH. Table 2 outlines the details of major studies investigating the relationship between statin use and $\mathrm{ICH}$. As shown in the Table 2, these results are not consistent.

\section{Statins may improve the outcome of ICH}

After analyzing the clinical data of 2466 patients with $\mathrm{ICH}$, Dowlatshahi et al. [25] found that the patients who took statin before the occurrence of $\mathrm{ICH}$ had lower risk of severe ICH compared with the nonusers $(54.7 \%$ vs. $63.3 \%)$. In addition, among 537 statins users, 158 patients who discontinued its use on admission were more likely to have poor outcomes and higher 30-day mortality (71\% vs. $21 \%, P<0.01)$ compared with those who took statin continuously [25]. A retrospective cohort study showed that $\mathrm{ICH}$ patients who started statin therapy during hospitalization had a lower 30-day mortality rate than statin nonusers $(18.4 \%$ vs. $38.7 \%, P<0.001)$ and were more likely to be discharged to their homes or an acute rehabilitation facility $(51.1 \%$ vs. $22.3 \%, P<$ 0.001) [9]. Pan et al. [26], using a multivariable logistic regression model adjusted for confounding factors, demonstrated that statin use during hospitalization for $\mathrm{ICH}$ patients was associated with more than $50 \%$ lower mortality rate at 3 months (adjusted OR 0.44, $95 \%$ CI $0.22-$ $0.87, P<0.001$ ) and 1 year (adjusted OR $0.49,95 \% \mathrm{CI}$ $0.27-0.86, P=0.02$ ) compared with those without statin therapy during admission.

It is believed statin may have the pleiotropic effects besides reducing serum lipid level. Using Magnetic Resonance Image (MRI) and immunohistochemistry, Yang et al. [27] found that simvastatin may protect the integrity of the blood-brain barrier (BBB) to prevent the dysfunction of it, resulting in the reduction of neurotoxic substances and white blood cells into the brain parenchyma [28, 29]. In addition, quantitative analysis showed simvastatin could improve the cerebral blood flow $(\mathrm{CBF})$ and promote the functional recovery of cerebrum [27]. In experiments with rats, it was demonstrated that statins could reduce the activation of glial cells [30] and the release of the cytokines such as IL-1B and TNF- $\alpha$ by microglia and brain-derived neurotrophic factors [4], suppress phagocytosis of microglia [4], inhibit the oxidative stress and development of inflammatory reaction [30], decrease the cell necrosis around the hematoma [30, 31], and promote the recovery of the sensorimotor function [31]. Yang et al. [32] found that statins could also promote the hyperplasia of the ependymal lower cells in Wistar rats and the formation of synapses and increase vascular density in the hematoma boundary zone, resulting in a better functional recovery of the nervous system.

\section{Statins may be independent of ICH}

A randomized and double-blinded trial [33], in which 20,536 adults with cerebrovascular disease, coronary heart disease, other occlusive arterial disease, diabetes or hypertension were randomly allocated $40 \mathrm{mg}$ simvastatin daily or matching placebo, indicated that statin therapy was not associated with hemorrhagic stroke $(0.5 \%$ vs. $0.5 \%$, OR 0.95, $95 \%$ CI 0.65-1.40, P = 0.8) during a mean 4.8 year follow-up period. A retrospective cohort study [34] involving 17,872 subjects aged 66 years and older who initiated statin therapy after acute ischemic stroke, demonstrated that there was no association between statin and $\mathrm{ICH}$ by the analysis comparing statin users with non-users (OR 0.87, 95 \% CI 0.65-1.17). Hackam et al. [35] conducted a meta-analysis of 23 random trials and 19 observational studies (12 cohort studies, six case-control studies and one case-crossover study) which comprised 248,391 patients with atherosclerotic cardiovascular disease or risk factors for atherosclerosis, of which 14,784 were $\mathrm{ICH}$ patients. And the results showed there was no significant association between statin use and $\mathrm{ICH}$ in the random trials (OR 1.10, $95 \%$ CI 0.86-1.14), cohort studies (OR 0.94, 95 \% CI 0.81-1.10) and case-control studies (OR 0.60, $95 \% \mathrm{CI}$ 0.41-0.88). McKinney et al. [36] made a meta-analysis of 31 randomized controlled trials about statin therapy and a total of 182,803 subjects were included $(91,588$ in the active group and 91,215 in the control group). Three hundred and fifty-eight patients in the active group suffered ICH versus three hundred and eighteen in the control group, indicated that there is no association between statin and ICH (OR 1.08, 95 \% CI 0.88-1.32, P $=0.47$ ). Meta regression analysis demonstrated there was 
Table 2 Summary of clinical studies investigating the relationship between statin use and ICH

\begin{tabular}{|c|c|c|c|c|c|c|c|c|c|}
\hline Study & Study design & $\begin{array}{l}\text { Sample size, } n \\
(\text { statin group, } n \text { ) }\end{array}$ & $\begin{array}{l}\text { Population or } \\
\text { settings }\end{array}$ & Statin & Dose & $\begin{array}{l}\text { Mean } \\
\text { age, y; male (\%) }\end{array}$ & Follow-Up in years & $\begin{array}{l}\text { ICH patients, } \\
n \text { (statin group, } n)\end{array}$ & Outcome \\
\hline $\begin{array}{l}{[25]} \\
\text { Dowlatshahi } \\
\text { et al. } 2012\end{array}$ & case-control study & $\begin{array}{l}2466 \text { ( } 537 \text { took } \\
\text { statin before the } \\
\text { occurrence of ICH, } \\
\text { statins were } \\
\text { discontinued on } \\
\text { admission in } 158 \text { of } \\
\text { 537) }\end{array}$ & $\begin{array}{l}\text { be admitted to } \\
\text { hospital with primary } \\
\text { ICH, Canadian }\end{array}$ & $\begin{array}{l}\text { No } \\
\text { details }\end{array}$ & no details & $71 ; 53.6 \%$ & / & / & $\begin{array}{l}\text { Compared with nonusers, statin } \\
\text { users were less likely to have } \\
\text { severe strokes ( } 54.7 \% \text { vs. } 63.3 \%) \\
\text { but had similar rates of poor } \\
\text { outcome ( } 70 \% \text { vs. } 67 \% \text { ) and } \\
30 \text {-day mortality ( } 36 \% \text { vs. } 37 \%) \text {. } \\
\text { The patients who discontinued } \\
\text { statins on admission were more } \\
\text { likely to have severe stroke ( } 65 \% \text { vs } \\
27 \%, P<0.01), \text { poor outcome } \\
(90 \% \text { vs. } 62 \%, P<0.01)\end{array}$ \\
\hline $\begin{array}{l}\text { [9] Flint } \\
\text { et al. } 2014\end{array}$ & $\begin{array}{l}\text { retrospective cohort } \\
\text { study }\end{array}$ & 3481 (1194) & $\begin{array}{l}\text { be admitted to } \\
\text { hospital with ICH, } \\
\text { American }\end{array}$ & $\begin{array}{l}\text { Lov, } \\
\text { Sim, } \\
\text { Ato }\end{array}$ & $\begin{array}{l}10 \mathrm{mg} / \mathrm{d} \text {, in } \\
\text { atorvastatin- } \\
\text { equivalent } \\
\text { dose }\end{array}$ & $73.5 ; 50.1 \%$ & No details & / & $\begin{array}{l}\text { Improved 30-day survival: OR } 4.25 \\
(95 \% \text { Cl 3.46-5.23) }\end{array}$ \\
\hline $\begin{array}{l}\text { [26] Pan } \\
\text { et al. } 2014\end{array}$ & case-control study & $3218(220)$ & $\begin{array}{l}\text { be admitted to } \\
\text { hospital with } \\
\text { ischemic stroke, ICH } \\
\text { or TIA, Chinese }\end{array}$ & $\begin{array}{l}\text { No } \\
\text { details }\end{array}$ & a/ & $62.1 ; 61.2 \%$ & 1 & / & $\begin{array}{l}\text { Improved } 3 \text { months and } 1 \text { year } \\
\text { survival: } 3 \text { months-survival: OR } 2.24 \\
\text { (95\%Cl 1.49-3.36); } 1 \text { year survival: } \\
\text { OR } 2.04 \text { (95\%Cl 1.37-3.06) }\end{array}$ \\
\hline $\begin{array}{l}\text { [7] Chen } \\
\text { et al. } 2014\end{array}$ & $\begin{array}{l}\text { population-based } \\
\text { prospective cohort } \\
\text { study }\end{array}$ & 8333 (749) & $\begin{array}{l}\text { be admitted to } \\
\text { hospital with new- } \\
\text { onset ICH, Taiwanese }\end{array}$ & $\begin{array}{l}\text { Sim, } \\
\text { Pra, } \\
\text { Flu }\end{array}$ & $\begin{array}{l}20 \mathrm{mg} / \mathrm{d} \text {, in } \\
\text { atorvastatin- } \\
\text { equivalent } \\
\text { dose }\end{array}$ & $59 ; 60.4 \%$ & 2 & $746(69)$ & $\begin{array}{l}\text { Did not increase the risk of } \\
\text { recurrent ICH: adjusted HR } 1.044 \\
\text { ( } 95 \% \mathrm{Cl} 0.812-1.341 \text { ) }\end{array}$ \\
\hline $\begin{array}{l}\text { [33] Collins } \\
\text { et al. } 2004\end{array}$ & $\begin{array}{l}\text { randomized } \\
\text { controlled trails }\end{array}$ & $20,536(10,269)$ & $\begin{array}{l}\text { with a history of } \\
\text { cardiovascular } \\
\text { disease, other } \\
\text { occlusive arterial } \\
\text { disease, diabetes, or } \\
\text { hypertension, British }\end{array}$ & Sim & $40 \mathrm{mg} / \mathrm{d}$ & $40-80 ; 75 \%$ & $\begin{array}{l}4.8 \text { (mean } \\
\text { duration) }\end{array}$ & $1029(444)$ & $\begin{array}{l}\text { No effect on ICH: OR } 0.95(95 \% \mathrm{Cl} \\
0.65-1.40)\end{array}$ \\
\hline $\begin{array}{l}\text { [34] Hackam } \\
\text { et al. } 2012\end{array}$ & $\begin{array}{l}\text { retrospective cohort } \\
\text { study }\end{array}$ & $17,872(8936)$ & $\begin{array}{l}\text { with a history of } \\
\text { acute ischemic } \\
\text { stroke, Canadian }\end{array}$ & $\begin{array}{l}\text { No } \\
\text { details }\end{array}$ & l & $77.9 ; 46.3 \%$ & 4.2 & 213 & $\begin{array}{l}\text { No effect on ICH: HR } 0.87(95 \% \mathrm{Cl} \\
0.65-1.17)\end{array}$ \\
\hline $\begin{array}{l}\text { [35] Hackam } \\
\text { et al. } 2011\end{array}$ & $\begin{array}{l}\text { meta-analysis ( } 23 \\
\text { randomized } \\
\text { controlled trails, } 12 \\
\text { cohort studies, } 6 \\
\text { case-control studies, } \\
1 \text { case-crossover } \\
\text { study) }\end{array}$ & 248,391 & $\begin{array}{l}\text { Patients with } \\
\text { atherosclerotic } \\
\text { cardiovascular } \\
\text { disease or risk factors } \\
\text { for atherosclerosis, } \\
\text { multicenter }\end{array}$ & $\begin{array}{l}\text { No } \\
\text { details }\end{array}$ & I & $/, /$ & $3.9(\mathrm{IQR}, 2.8-5.0)$ & 14,784 & $\begin{array}{l}\text { No effect on ICH: random trials: OR } \\
1.10 \text { (95 \% Cl 0.86-1.14); cohort } \\
\text { studies: OR } 0.94 \text { ( } 95 \% \text { Cl 0.81-1.10); } \\
\text { case-control studies: OR } 0.60 \text { ( } 95 \% \\
\text { Cl 0.41-0.88) }\end{array}$ \\
\hline $\begin{array}{l}{[36]} \\
\text { McKinney } \\
\text { et al. } 2012\end{array}$ & $\begin{array}{l}\text { meta-analysis ( } 31 \\
\text { randomized } \\
\text { controlled trails) }\end{array}$ & $\begin{array}{l}182,803 \text { ( } 91,588 \text { in } \\
\text { the active group } \\
\text { and } 91,215 \text { in the } \\
\text { control group) }\end{array}$ & $\begin{array}{l}\text { Patients with a } \\
\text { history of diabetes } \\
\text { mellitus, } \\
\text { hypertension, } \\
\text { cardiovascular } \\
\text { disease, stroke or } \\
\text { smoking, multicenter }\end{array}$ & / & / & $62.6 ; 67.0 \%$ & $\begin{array}{l}3.9 \text { (median } \\
\text { length) }\end{array}$ & $\begin{array}{l}676 \text { ( } 358 \text { patients } \\
\text { in the active } \\
\text { group vs. } 318 \text { in } \\
\text { the control } \\
\text { group) }\end{array}$ & $\begin{array}{l}\text { No effect on ICH: OR } 1.08(95 \% \mathrm{Cl} \\
0.88-1.32)\end{array}$ \\
\hline
\end{tabular}


Table 2 Summary of clinical studies investigating the relationship between statin use and ICH (Continued)

\begin{tabular}{|c|c|c|c|c|c|c|c|c|c|}
\hline $\begin{array}{l}\text { [21] } \\
\text { Mustanoja } \\
\text { et al. } 2013\end{array}$ & observational registry & $\begin{array}{l}964 \text { (187 patients } \\
\text { used statin before } \\
\text { ICH) }\end{array}$ & ICH patients, Finnish & $\begin{array}{l}\text { No } \\
\text { details }\end{array}$ & / & $66 ; 57 \%$ & No details & / & $\begin{array}{l}\text { Premorbid statin use did not affect } \\
\text { the outcome of ICH[in-hospital } \\
\text { mortality: OR } 1.11 \text { ( } 95 \% \mathrm{Cl} 0 . \\
\text { 39-3.14); 3-month } \\
\text { mortality: OR } 1.57 \text { ( } 95 \% \mathrm{Cl} 0.74- \\
\text { 3.32); } \\
\text { 12-month mortality: OR } 0.97 \text { (95\% } \\
\text { Cl 0. } \\
\text { 48-1.96)] }\end{array}$ \\
\hline $\begin{array}{l}\text { [14] Lei et al. } \\
2014\end{array}$ & $\begin{array}{l}\text { meta-analysis ( } 12 \\
\text { interventional or } \\
\text { observational clinical } \\
\text { studies) }\end{array}$ & $\begin{array}{l}\text { 6961(1652 patients } \\
\text { used statin before } \\
\text { ICH and } 5309 \\
\text { nonusers }\end{array}$ & $\begin{array}{l}\text { ICH patients, } \\
\text { multicenter }\end{array}$ & $\begin{array}{l}\text { Pra, } \\
\text { Sim, } \\
\text { Ato }\end{array}$ & $\begin{array}{l}10-40 \mathrm{mg} / \\
\text { day }\end{array}$ & $/, /$ & No details & $2423(569)^{a}$ & $\begin{array}{l}\text { No effect on } \\
\text { in-hospital, 30-day and 90-day } \\
\text { mortality: OR } 0.85 \text { ( } 95 \% \\
\text { Cl 0.70-1.03) }\end{array}$ \\
\hline $\begin{array}{l}{[37]} \\
\text { Amarenco } \\
\text { et al. } 2006\end{array}$ & $\begin{array}{l}\text { prospective random } \\
\text { study }\end{array}$ & $4731(2365)$ & $\begin{array}{l}\text { with a history of an } \\
\text { ischemic or } \\
\text { hemorrhagic stroke } \\
\text { or a TIA, multicenter }\end{array}$ & Ato & $80 \mathrm{mg} / \mathrm{d}$ & $62.7 ; 59.6 \%$ & $4.9(4.0-6.6)$ & $88(55)$ & $\begin{array}{l}5 \text {-year absolute reduction in the risk } \\
\text { of fatal or nonfatal stroke: adjusted } \\
\text { HR } 0.84 \text { ( } 95 \% \text { Cl } 0.71-0.99 \\
P=0.03 \text { ) }\end{array}$ \\
\hline $\begin{array}{l}\text { [10] } \\
\text { Goldstein } \\
\text { et al. } 2007^{\mathrm{b}}\end{array}$ & $\begin{array}{l}\text { the post hoc analysis } \\
\text { of prospective } \\
\text { random study }\end{array}$ & $4731(2365)$ & $\begin{array}{l}\text { with a history of an } \\
\text { ischemic or } \\
\text { hemorrhagic stroke } \\
\text { or a TIA, multicenter }\end{array}$ & Ato & $80 \mathrm{mg} / \mathrm{d}$ & $62.7 ; 59.6 \%$ & $4.9(4.0-6.6)$ & $88(55)$ & $\begin{array}{l}\text { Increased the risk of ICH: } 2.3 \% \text { vs. } \\
1.4 \% \text {, HR } 1.68 \text { ( } 95 \% \mathrm{Cl} 1.09-2.59)\end{array}$ \\
\hline $\begin{array}{l}\text { [1] Scheitz } \\
\text { et al. } 2014\end{array}$ & $\begin{array}{l}\text { prospective cohort } \\
\text { study }\end{array}$ & $\begin{array}{l}1446 \text { ( } 317 \text { used } \\
\text { statins before } \\
\text { intravenous } \\
\text { thrombolysis) }\end{array}$ & $\begin{array}{l}\text { acute ischemic } \\
\text { stroke patients } \\
\text { receiving intravenous } \\
\text { thrombolysis, } \\
\text { American }\end{array}$ & $\begin{array}{l}\text { Sim, } \\
\text { Ato, } \\
\text { Pra, } \\
\text { Flu, } \\
\text { Ros }\end{array}$ & $\begin{array}{l}20,40, \\
80 \mathrm{mg} / \mathrm{d} \text {, in } \\
\text { simvastatin- } \\
\text { equivalent } \\
\text { dose }\end{array}$ & $66.5 ; 66.0 \%$ & / & 53 & $\begin{array}{l}\text { Enhanced the risk of sICH: adjusted } \\
\text { OR } 2.4(95 \% \mathrm{Cl} 1.1 .5 .3) \text { and } 5.3 \\
(95 \% \mathrm{Cl} 2.3-12.3)^{\mathrm{c}}\end{array}$ \\
\hline
\end{tabular}

TIA transient ischemic attack, SPARCL stroke prevention by aggressive reduction in cholesterol levels, HR hazard ratio, OR odds ratio, RR risk ratio, Lov lovastatin, Sim simvastatin, Ato atorvastatin, Pra pravastatin, Flu fluvastatin, Ros rosuvastatin

total events

analysis of SPARCL study (Amarenco et al. [37])

c for sICH for patients with medium or high-dose statins compared with non-statin users 
no relationship between the risk of $\mathrm{ICH}$ and (i) the degree of the LDL-C reduction (slope, 0.0043; SE, 0.0054; $95 \% \mathrm{CI},-0.4831$ to $0.0149 ; P=0.43$ ); (ii) the achieved level of LDL-C in the active treatment group (slope, -0.0049 ; SE, 0.0043 ; $95 \% \mathrm{CI},-0.0133$ to $0.0035 ; P=$ 0.26). In addition, the Helsinki ICH Study composed of 964 ICH patients [21] showed admission (23\% vs. $24 \%$, $P=0.785), 3$ months $(34 \%$ vs. $32 \%, P=0.449)$ and 12 months (38\% vs. $36 \%, P=0.602$ ) mortality did not differ between the patients who used statin before hospitalization and those who did not. It suggested that statin therapy before admission had no effect on the prognosis of $\mathrm{ICH}$ patients. Another meta-analysis of 12 studies which included 1652 patients who used statins before ICH and 5309 nonusers [14] demonstrated statin did not have a significant effect on the improvement of the admission, 30-day and 90-day mortality (OR 0.85, $95 \%$ CI $0.70-1.03)$. The proportion of the patients receiving a Rankin score of 3-6 (OR 0.82, 95 \% CI 0.601.11 ) or 4-6 (OR $0.79,95 \%$ CI $0.43-1.45$ ) was not changed when premorbid statin was used. In other words, premorbid statin therapy did not improve the functional outcome significantly [14]. Furthermore, the volume of hematoma was not affected significantly with premorbid statin therapy [14]. A population-based prospective cohort study also revealed statin therapy initiated during admission or within 3 months after discharge did not increase the risk of recurrent ICH [7].

\section{Statins may promote ICH}

The Stroke Prevention by Aggressive Reduction in Cholesterol Levels (SPARCL) study [37] is the only secondary prevention study by now to evaluate the effect of statin therapy in non-cardiac ischemic stroke or transient ischemic attack (TIA) associated with hypercholesterolemia. The study included 4731 patients, who had a history of stroke or TIA within 1-6 months and a serum LDL-C level of at least 100-190 mg/dl but did not have any known coronary heart disease. These patients were randomly allocated to the active group (80 $\mathrm{mg}$ atorvastatin daily) or control group (matched placebo). The results showed that decreased cholesterol level was associated with less risk of recurrent stroke. But the post hoc analysis [10] found that there were more hemorrhagic stroke patients in the treatment group than those in the placebo group (2.3\% vs. $1.4 \%$, HR 1.68, 95 \% CI 1.09-2.59). Cox multivariable regression analysis showed that a hemorrhagic stroke as the entry event (HR 5.65, $95 \%$ CI 2.82-11.30, $p<0.001$ ), male (HR 1.79, 95 \% CI 1.13-2.84, $P=0.01$ ), age (10 y increments, HR 1.42, $95 \%$ CI 1.16-1.74, $P=0.001)$ and having Stage 2 (JNC-7) hypertension (HR 6.19, $95 \% \mathrm{CI}$ 1.47-26.11, $P=0.01$ ) were independently associated with the risk of hemorrhagic stroke. Scheitz, JF et al. [1] analyzed data from two European intravenous thrombolysis registries and found that 317 (22\%) used statins before intravenous thrombolysis among 1446 acute ischemic stroke patients and the frequency of symptomatic $\mathrm{ICH}$ was $2 \%, 6 \%$, and $13 \%$ in patients with low-, medium-, and high-dose statin (simvastatin 20, 40, $80 \mathrm{mg} / \mathrm{d}$ or equivalent) treatment, respectively $(P<0.01)$, which indicated that there was a correlation between the increasing dose of statin therapy and risk of $\mathrm{ICH}$ among patients who had been treated with simvastatin or atorvastatin.

These inconsistent results may be caused by different population and dosage of stains when the relationship between stain therapy and $\mathrm{ICH}$ was studied. As shown in Table 2, a majority of randomized controlled trials [33] and the meta-analyses [35, 36] which included the patients with a history of atherosclerotic cardiovascular disease or the subjects with risk factors for atherosclerosis (such as diabetes, hypertension or smoking) showed that statin use did not affect the occurrence or outcome of $\mathrm{ICH}$. But certain patients with history of ICH or high risk of $\mathrm{ICH}$ appear to be at increased risk of brain hemorrhages when exposed to high-dose statin [1, 37]. Mustanoja et al. [21] reasoned that statin therapy could increase the risk of $\mathrm{ICH}$ because low serum cholesterol level may lead to the reduction of vessel resistance to tension, resulting in higher risk of rupture and hemorrhage.

\section{Conclusion}

Although epidemiological investigation found that the population with lower serum TC and LDL-C levels had a higher risk of $\mathrm{ICH}$, the reduction of blood lipid levels caused by statin therapy might not increase the risk of $\mathrm{ICH}$. Based on the current data, we think statin use in the prevention and treatment of atherosclerotic cardiovascular disease does not increase the risk of $\mathrm{ICH}$ in most conditions. The pleiotropic effects of statins such as inhibition of inflammation and protection of $\mathrm{BBB}$ may improve the prognosis of acute hemorrhagic stroke patients. But for elderly patients who have history of $\mathrm{ICH}$ and poorly-controlled hypertension, statins especially used in high dose, may increase the risk of $\mathrm{ICH}$. Therefore, patients with low TC and LDL-C and high risk of $\mathrm{ICH}$ should be cautious in the usage of statins.

\section{Abbreviations}

ICH: intracerebral hemorrhage; sICH: symptomatic intracerebral hemorrhage; CMB: cerebral microbleed; TNF-a: tumor necrosis factor- $\alpha$; IL-1 $\beta$ : interleukin1ß; BBB: blood-brain barrier; TC: total cholesterol; TG: triglyceride; LDL-C: low density lipoprotein cholesterol; HDL-C: high density lipoprotein cholesterol; ZO-1: zona occuludens-1; HAEC: human arterial endothelial cell; CBF: cerebral blood flow. 


\section{Competing interests}

The authors declare that they have no competing interests.

\section{Authors' contributions}

$\mathrm{XL}$ conceived the idea; YM wrote the manuscript; YM, ZL and LC collected and read the literature; $X \mathrm{~L}$ read through and corrected the manuscript. All authors read and approved the final manuscript.

\section{Acknowledgments}

No.

\section{Author details}

'Department of Cardiology, The Second Xiangya Hospital, Central South University, \#139 Middle Renmin Road, Changsha, Hunan 410011, PR China. ${ }^{2}$ The Eight-Year Clinical Medicine of Grade 2012, Xiangya School of Medicine, Central South University, Changsha, Hunan 410013, PR China.

\section{Received: 3 October 2015 Accepted: 24 February 2016}

Published online: 01 March 2016

\section{References}

1. Scheitz JF, Seiffge DJ, Tutuncu S, Gensicke H, Audebert HJ, Bonati LH, et al. Dose-related effects of statins on symptomatic intracerebral hemorrhage and outcome after thrombolysis for ischemic stroke. Stroke. 2014;45(2):50914.

2. Romero JR, Preis SR, Beiser A, DeCarli C, Viswanathan A, Martinez-Ramirez S, et al. Risk factors, stroke prevention treatments, and prevalence of cerebral microbleeds in the Framingham Heart Study. Stroke. 2014;45(5):1492-4.

3. Sansing LH, Harris TH, Welsh FA, Kasner SE, Hunter CA, Kariko K. Toll-like receptor 4 contributes to poor outcome after intracerebral hemorrhage. Ann Neurol. 2011:70(4):646-56.

4. Churchward MA, Todd KG. Statin treatment affects cytokine release and phagocytic activity in primary cultured microglia through two separable mechanisms. Mol Brain. 2014;7:85

5. Ye X, Chopp M, Cui X, Zacharek A, Cui Y, Yan T, et al. Niaspan enhances vascular remodeling after stroke in type 1 diabetic rats. Exp Neurol. 2011; 232(2):299-308.

6. Tsai CF, Anderson N, Thomas B, Sudlow CL. Risk factors for ischemic stroke and its subtypes in Chinese vs. Caucasians: Systematic review and metaanalysis. Int J Stroke. 2015;10(4):485-93.

7. Chen PS, Cheng CL, Chang YC, Kao YY, Yeh PS, Li YH. Early statin therapy in patients with acute intracerebral hemorrhage without prior statin use. Eur J Neurol. 2015;22(5):773-80.

8. Heart Protection Study Collaborative Group. MRC/BHF Heart Protection Study of cholesterol lowering with simvastatin in 20,536 high-risk individuals: a randomised placebo-controlled trial. Lancet. 2002:360(9326):7-22.

9. Flint AC, Conell C, Rao VA, Klingman JG, Sidney S, Johnston SC, et al. Effect of statin use during hospitalization for intracerebral hemorrhage on mortality and discharge disposition. JAMA Neurol. 2014;71(11):1364-71.

10. Goldstein LB, Amarenco P, Szarek M, Callahan AR, Hennerici M, Sillesen H, et al. Hemorrhagic stroke in the Stroke Prevention by Aggressive Reduction in Cholesterol Levels study. Neurology. 2008;70(24 Pt 2):2364-70.

11. Bonaventure A, Kurth T, Pico F, Barberger-Gateau P, Ritchie K, Stapf C, et al. Triglycerides and risk of hemorrhagic stroke vs. ischemic vascular events: The Three-City Study. Atherosclerosis. 2010;210(1):243-8.

12. Zhang $Y$, Tuomilehto J, Jousilahti $P$, Wang $Y$, Antikainen $R$, Hu G. Total and high-density lipoprotein cholesterol and stroke risk. Stroke. 2012:43(7):1768-74.

13. O'Donnell MJ, Xavier D, Liu L, Zhang H, Chin SL, Rao-Melacini P, et al. Risk factors for ischaemic and intracerebral haemorrhagic stroke in 22 countries (the INTERSTROKE study): a case-control study. Lancet. 2010;376(9735):112-23.

14. Lei C, Wu B, Liu M, Chen Y. Association between statin use and intracerebral hemorrhage: a systematic review and meta-analysis. Eur J Neurol. 2014;21(2):192-8.

15. Sturgeon JD, Folsom AR, Longstreth WJ, Shahar E, Rosamond WD, Cushman M. Risk factors for intracerebral hemorrhage in a pooled prospective study. Stroke. 2007:38(10):2718-25.

16. Wieberdink RG, Poels MM, Vernooij MW, Koudstaal PJ, Hofman A, van der Lugt A, et al. Serum lipid levels and the risk of intracerebral hemorrhage: the Rotterdam Study. Arterioscler Thromb Vasc Biol. 2011;31(12):2982-9.
17. Zia E, Pessah-Rasmussen H, Khan FA, Norrving B, Janzon L, Berglund G, et al. Risk factors for primary intracerebral hemorrhage: a population-based nested case-control study. Cerebrovasc Dis. 2006;21(1-2):18-25.

18. Zhou JF, Wang JY, Luo YE, Chen HH. Influence of hypertension, lipometabolism disorders, obesity and other lifestyles on spontaneous intracerebral hemorrhage. Biomed Environ Sci. 2003;16(3):295-303.

19. Wang X, Dong Y, Qi X, Huang C, Hou L. Cholesterol levels and risk of hemorrhagic stroke: a systematic review and meta-analysis. Stroke. 2013; 44(7):1833-9.

20. Suzuki K, Izumi M, Sakamoto T, Hayashi M. Blood pressure and total cholesterol level are critical risks especially for hemorrhagic stroke in Akita Japan. Cerebrovasc Dis. 2011;31(1):100-6.

21. Mustanoja S, Strbian D, Putaala J, Meretoja A, Curtze S, Haapaniemi E, et al. Association of prestroke statin use and lipid levels with outcome of intracerebral hemorrhage. Stroke. 2013:44(8):2330-2.

22. Yamori $Y$, Nara $Y$, Horie $R$, Ooshima A. Abnormal membrane characteristics of erythrocytes in rat models and men with predisposition to stroke. Clin Exp Hypertens. 1980;2(6):1009-21.

23. Konishi M, Iso H, Komachi $Y$, lida M, Shimamoto $T$, Jacobs DJ, et al. Associations of serum total cholesterol, different types of stroke, and stenosis distribution of cerebral arteries. The Akita Pathology Study. Stroke. 1993:24(7):954-64

24. Stoney CM, West SG, Hughes JW, Lentino LM, Finney ML, Falko J, et al. Acute psychological stress reduces plasma triglyceride clearance. Psychophysiology. 2002;39(1):80-5.

25. Dowlatshahi D, Demchuk AM, Fang J, Kapral MK, Sharma M, Smith EE Association of statins and statin discontinuation with poor outcome and survival after intracerebral hemorrhage. Stroke. 2012;43(6):1518-23.

26. Pan $Y S$, Jing J, Wang $Y L$, Zhao $X Q$, Song $B$, Wang WJ, et al. Use of statin during hospitalization improves the outcome after intracerebral hemorrhage. CNS Neurosci Ther. 2014;20(6):548-55.

27. Yang D, Knight RA, Han Y, Karki K, Zhang J, Chopp M, et al. Statins Protect the Blood Brain Barrier Acutely after Experimental Intracerebral Hemorrhage. J Behav Brain Sci. 2013;3(1):100-6.

28. Keep RF, Xiang J, Ennis SR, Andjelkovic A, Hua Y, Xi G, et al. Blood-brain barrier function in intracerebral hemorrhage. Acta Neurochir Suppl. 2008; 105:73-7.

29. Lee KR, Kawai N, Kim S, Sagher O, Hoff JT. Mechanisms of edema formation after intracerebral hemorrhage: effects of thrombin on cerebral blood flow, blood-brain barrier permeability, and cell survival in a rat model. J Neurosurg. 1997:86(2):272-8

30. Indraswari F, Wang H, Lei B, James ML, Kernagis D, Warner DS, et al. Statins improve outcome in murine models of intracranial hemorrhage and raumatic brain injury: a translational approach. J Neurotrauma. 2012:29(7): 1388-400.

31. Jung KH, Chu K, Jeong SW, Han SY, Lee ST, Kim JY, et al. HMG-CoA reductase inhibitor, atorvastatin, promotes sensorimotor recovery, suppressing acute inflammatory reaction after experimental intracerebral hemorrhage. Stroke. 2004;35(7):1744-9.

32. Yang D, Zhang J, Han Y, James E, Chopp M, Seyfried DM. Acute Statin Treatment Improves Recovery after Experimental Intracerebral Hemorrhage. World J Neurosci. 2013;3(2):69-75.

33. Collins R, Armitage J, Parish S, Sleight P, Peto R. Effects of cholesterollowering with simvastatin on stroke and other major vascular events in 20536 people with cerebrovascular disease or other high-risk conditions. Lancet. 2004;363(9411):757-67.

34. Hackam DG, Austin PC, Huang A, Juurlink DN, Mamdani MM, Paterson JM, et al. Statins and intracerebral hemorrhage: a retrospective cohort study. Arch Neurol. 2012:69(1):39-45.

35. Hackam DG, Woodward M, Newby LK, Bhatt DL, Shao M, Smith EE, et al. Statins and intracerebral hemorrhage: collaborative systematic review and meta-analysis. Circulation. 2011;124(20):2233-42

36. McKinney JS, Kostis WJ. Statin therapy and the risk of intracerebral hemorrhage: a meta-analysis of 31 randomized controlled trials. Stroke. 2012;43(8):2149-56.

37. Amarenco P, Bogousslavsky J, Callahan AR, Goldstein LB, Hennerici M, Rudolph $A E$, et al. High-dose atorvastatin after stroke or transient ischemic attack. N Engl J Med. 2006:355(6):549-59. 